\title{
NOTES ON THE BIOGEOGRAPHY OF THE FREE-LIVING TERRESTRIAL INVERTEBRATE FAUNA OF MACQUARIE ISLAND WITH AN ANNOTATED CHECKLIST
}

\author{
by Pinelope Cireenslade
}

(with six lables and an appendix)

\begin{abstract}
GREENSLADE, P., 1990 (31:x): Noles on the biogeography of the free-living terrestral invertebrate latum of Macquarie Island with an annotated checklist. Pap Proc. R. Soc Tasm. 124(1): 35-50. https://doi.org/10.26749/rstpp.124.1.35 ISSN 0080-4703. CSIRO Division of Entomology, GPO Box 1700, Canberra. ACT Australia 2601.
\end{abstract}

The invertebrate fauna of Macquarie Island is examined and its siec, composition endemsity and biogecogtaphical alfinites are compared with those of other subantaretic islands. Its origins, dispersal mechamems and adtaptations are discussed and the effect on it of vertebrate predators considered. A checklist of the invertebrates known from Macquarte Island incorporating recent revisionary taxonomy is included as an appendix.

Key Words: Subantarctic, Insecta, Collembola, Mollusca, Oligochaeta, Arachnida, endemism.

\section{INTRODUCTION}

Prior to fieldwork carried out in the summer of $1986-87$ by the author, the only large collection of terrestrial invertebrates from Macquarie Island was that of Watson (1967) who recorded 144 species, of which he believed 49 (34\%) were endemic. A later work by Gressit (1970) added little further taxonomic information, although, for the first time, the invertebrate fauna of Macquarie Island was compared in detail with those of other subantarctic islands. Since then, revisionary taxonomy of a number of taxa has been published on the basis of more extensive material from throughout the subantarctic region (Selkirk et al. 1986). Using new information, a revised list has been compiled of species known from Macquarie Island (see appendix); this includes a number of new records. A trend observed, during its compilation, was a steady reduction in percentage endemism from the 1967 (Watson) and 1970 (Gressitt) figures. The level of endemism for Macquarie Island is now much lower than for other subantarctic islands and possible reasons for this are discussed here.

This new checklist excludes a number of the lower invertebrate taxa which are inadequately collected and does not cover freshwater species. of which there are very few. For example, although species of Protozoa (Watson 1967), Rotifera (Watson 1967), Turbellaria (Ball \& Hay 1977), Nematoda (Bunt 1954), Copepoda (Hamond 1987) and Cladocera (Smirnov \& Timms 1983) have been recorded from the island, most of these groups are still poorly known. All species so far recorded in them, apart from the Turbellaria, have widespread distributions.
Neither are the Acari listed here in detail. Womersley (1937a) published some of the earliest records of mites and, although good collections are available from Macquarie Island, the faunas of adjacent territories have mol been intensively studied so that any list presented here would give a misleadingly elevated figure lor the percentage endemism in this group (i.e. Wallwork 1973). (Over 80) species of mites have been identified (D. Horning, pers. comm.), but the fauna certainly contains more than this and no revisionary work has been carried out for about 20 years. For this reason they have not been included in the discussion. "Adventitious" species, which include those which disperse from lime to time to the island but are unable to establish permanent populations, i.e. naturalise. were listed by Watson (1967) and are not repeated here. The ectoparasitic Phthiraptera will be discussed in a latcr publication (D). Horning \& $\mathrm{R}$. Palma, pers. comm.).

Taxa are arranged as in Insects of Austrulia (CSIRO) 1970) and Greenslade (1985). Full synonymies are not given for the species which occur widely outside Macquarie Island but most names mentioned in publications on Macquarie Island are included, except for those of Collembola which have recently been given by Gicenslade \&Wise (1986). Distribution records of each spectes are included and specios are classilied according to whether they have been introduced relatively recently, probably by humans, or are considered native to the island. The method used to determine to which category each species belongs has been described by Greenslade (1987a). Material collected in 1986--87 is deposited either in the South Australian Museum 
(SAMA) (Collembola) or in the Australian National Insect Collection (ANIC) (all other invertebrates). Fieldwork was conducted in December 1986 and January 1987. Samples came from as many different habitats and sites on the island as possible and over 100 collections were made. Methods used included pitfall traps, funnel extraction of soil and leaf litter, sweeping and beating vegetation and searching under stones. A preliminary version of this checklist was published in Selkirk et al. (1990).

\section{CHARACTERISTICS OF THE MACQUARIE ISLAND FAUNA}

\section{Size}

So far as number of invertebrate species is concerned it is clear that the fauna is extremely small for a humid vegetated island of area 12800 ha $\left(120 \mathrm{~km}^{2}, 34 \times 2.5-5 \mathrm{~km}\right)$. Only 76 resident species of terrestrial arthropods, molluscs and oligochaetes (excluding mites) (Table 1) are recorded despite considerable collecting effort. Although some Diptera species are yet to be identified, it is unlikely that this list will be increased by much.

Taking a single group, the Collembola, of which 31 species are listed, five were found only in the greenhouse among the main station buildings. In contrast, one can generally find 30 species of Collembola on a site of $10 \mathrm{~m}^{2}$ in southern Australia. Even on Philip Island, a much smaller island $\left(3 \mathrm{~km}^{2}\right)$ off the coast of Norfolk Island in the Tasman Sea, and at that time practically denuded of vegetation, 25 species have been collected (P. Greenslade), while The Snares, an undisturbed island group north of Auckiand Island, similar in size to Philip Island, carries nearly 50 species of Collembola (P. Greenslade).

A comparison of the faunal size with that of other subantarctic islands is difficult because there are many variables in terms of latitude, area, climate, altitude, permanent snow cover and geological origin. (The term subantarctic islands is used here in its strict sense and includes only the Kerguelen, South Georgia, Heard, Prince Edward group (including Marion Island), Crozet and Macquarie Islands.) The most similar island to Macquarie Island appears to be Marion Island. Although being of volcanic origin, rather than raised seafloor as is Macquarie Island (Williamson 1988), it is of similar size, lies at a similar latitude (Table 3), is of a similar age (Bakker et al. 1971) and the invertebrate fauna is becoming well known (Crafford 1984, 1986, Crafford \& Scholtz 1987, Crafford et al.
1986). Twenty-six insect species have been recorded from Marion Island compared with 31 from Macquarie Island (Table 4).

Returning to the Collembola, the size of the Macquarie Island fauna is of the same order of magnitude as those of the Kerguelen and Crozet Islands (Deharveng 1981) but if only native species are included, it is smaller (Table 5). Marion Island has a smaller fauna but it is probably undercollected while Heard Island, which has little ice-free area and then for only a short period in the summer, has an even smaller fauna (Greenslade 1986). Until Collembola have been collected from the other subantarctic islands as intensively as from Macquarie Island, further comment cannot be made about relative size of faunas.

\section{Composition}

The representation of higher taxa on Macquarie Island is very uneven. There are as many collembolan as insect species. Among the insects, the Diptera are the best represented group but only two families of Coleoptera are present and among the other large orders, there are few Hemiptera, Lepidoptera and Hymenoptera.

The composition of the insect fauna is similar to that of Marion Island in that five of the same orders of native insects occur. The main differences lie in that there are no Curculionidae, fewer Lepidoptera but more Staphylinidae and Diptera species on Macquarie Island (Table 4) compared with Marion Island.

The composition of collembolan faunas, so far as genera are concerned, is similar on all the subantarctic islands; genera such as Cryplopygus and Tullhergia are the most diverse and are characteristic of these faunas. The Kerguelen Islands have the largest and most varied collembolan fauna in terms of both genera and species (Deharveng 1981).

\section{Endemism}

A high level of endemism (34\%), was recorded for Macquarie Island invertebrates by Watson (1967); when mites were excluded, this increased to about $40 \%$ (Table 2). Watson listed 20 endemic insects of which a number have now been recorded elsewhere or have been synonymised with other species. Gressitt (1970) stated there were 25 endemic species of insects out of a total of $40(62 \%)$ including Collembola. There now appear to be only ten current endemics (c. $18 \%$ - two Collembola, six Diptera 
TABLE 1

Terrestrial Invertebrates of Macquarie Island Excluding Mites

\begin{tabular}{lcccc}
\hline Order & $\begin{array}{c}\text { Number of species } \\
\text { probably introduced } \\
\text { and now naturalised }\end{array}$ & $\begin{array}{c}\text { Number of species } \\
\text { introduced but } \\
\text { not naturalised }\end{array}$ & $\begin{array}{c}\text { Number of native } \\
\text { and endemic } \\
\text { species }\end{array}$ & $\begin{array}{c}\text { Total } \\
\text { number } \\
\text { of species }\end{array}$ \\
\hline $\begin{array}{l}\text { Oligochaeta } \\
\text { Mollusca }\end{array}$ & 1 & - & 7 & 8 \\
Collembola & 1 & - & 3 & 4 \\
Psocoptera & 5 & 5 & 21 & 31 \\
Thysanoptera & - & - & 1 & 1 \\
Hemiptera & - & - & 1 & 1 \\
Diptera & 3 & - & - & 3 \\
Coleoptera & 2 & 1 & 12 & 15 \\
Lepidoptera & - & - & 8 & 8 \\
Hymenoptera & - & - & 1 & 2 \\
Araenae & - & - & 2 & 2 \\
& - & - & 58 & $76+88$ mites \\
\hline
\end{tabular}

TABLE 2

Numbers and Percentages of Endemic Species on Macquarie Island*

\begin{tabular}{|c|c|c|c|c|}
\hline & \multicolumn{2}{|c|}{ Number of endemic species } & \multicolumn{2}{|c|}{ Percentage of endemic species } \\
\hline & $1967 \& 1970$ & 1987 & $1967 \& 1970$ & 1987 \\
\hline Oligochaeta & 1 & 2 & 17 & 33 \\
\hline Mollusca & 1 & 0 & 25 & 0 \\
\hline Collembola & $3(9)$ & $2+2 ? \dagger$ & 33 & $6-12 \dagger$ \\
\hline Diptera & 10 & 6 & 66 & $31 \dagger$ \\
\hline Thysanoptera & 1 & 0 & 100 & 0 \\
\hline Psocoptera & 1 & 0 & 100 & 0 \\
\hline Hemiptera & 0 & 0 & 0 & 0 \\
\hline Coleoptera & 1 & 0 & 12 & $0+$ \\
\hline Hymenoptera & $1+1 ?$ & 0 & 100 & 0 \\
\hline Lepidoptera & 1 & 0 & 100 & 0 \\
\hline Araneae & & 0 & 0 & 0 \\
\hline Mollusca & & 0 & 0 & 0 \\
\hline Endemic species & $20+1 ?$ & $10+2 ?$ & $-40 \%$ & $-17 \%$ \\
\hline Total species & 51 & 76 & & \\
\hline
\end{tabular}

* Recorded by Watson (1967) and Gressitt (1970), and those currently known.

$\dagger$ Taxonomic studies not yet complete. 
TABLE 3

Comparison of Physical Characteristics of Marion and Macquarie Islan es:

Marion Island

Areat $\left(\mathrm{km}^{2}\right)$

Permanent ice cover (ha)

Arca below $500 \mathrm{~m}$ (ha)

Latiude $\left({ }^{\circ} \mathrm{C}\right)$

Temperature of the coldest month $\left({ }^{\circ} \mathrm{C}\right)$

Distance from nearest mainland $(\mathrm{km})$

Distance from nearest land $(\mathrm{km})$

Distance from nearest land westward within $10^{\circ}$ latitude $(\mathrm{km})$

Mean annual temperature $\left({ }^{\circ} \mathrm{C}\right)$

Mean annual precipitation ( $\mathrm{mm})$

Age (years)

Number of species of vascular plants

290
50
150
46.9
33
1900
1900

3270
5.1
2575
million BP
22

22
Macquarite Istand
IIf
118
54.6
990
610
$540 !$
5.0
903

est. $>100000$ to $<1$ million $\mathrm{BP}$ 45

* From Abbott (1974).

TABLE 4

Comparison of Number of Insect Species Known from the Prince Edward Group* and Macquarie Island

\begin{tabular}{|c|c|c|c|c|c|c|}
\hline & \multicolumn{3}{|c|}{ Prince Edward Group } & \multicolumn{3}{|c|}{ Macquarie Istand } \\
\hline & $\begin{array}{l}\text { Native and } \\
\text { endemic } \\
\text { species }\end{array}$ & $\begin{array}{l}\% \text { endemic } \\
\text { species } \\
\text { (nos) }\end{array}$ & $\begin{array}{l}\text { Naturalised } \\
\text { aliens }\end{array}$ & $\begin{array}{l}\text { Native and } \\
\text { endemic } \\
\text { species }\end{array}$ & $\begin{array}{l}\% \text { endemic } \\
\text { species } \\
\text { (nos) }\end{array}$ & $\begin{array}{c}\text { Naturalised } \\
\text { aliens }\end{array}$ \\
\hline \multicolumn{7}{|l|}{ Insects } \\
\hline Psocoptera & 1 & 0 & 0 & 1 & 0 & 0 \\
\hline Thysanoptera & 0 & 0 & 1 & 1 & () & 0 \\
\hline Hemiptera & 0 & 0 & 3 & 0 & 0 & 3 \\
\hline Coleoptera & 7 & $43(3)$ & 0 & 8 & 0 & 0 \\
\hline Diptera & 5 & $49(2)$ & 4 & $4 ?$ & $46(6)(+1 ?)$ & 2 \\
\hline Lepidoptera & 3 & $33(1)$ & 1 & 1 & 0 & 0 \\
\hline Hymenoptera & 1 & 0 & () & 2 & 0 & 0 \\
\hline Totals & 17 & $35(6)$ & 9 & 26 & $23(0)$ & 5 \\
\hline Collembola & 13 & $15(2)$ & 0 & 21 & $10(2)+2 y$ & 10 \\
\hline
\end{tabular}

* Includes Marion Island

+ From Crafford et al. (1986) 
TABLE 5

Comparison of Collembolan Faunas of Subantarctic Islands

\begin{tabular}{lccccc}
\hline Island & $\begin{array}{c}\text { Total number } \\
\text { of native and } \\
\text { endemic species }\end{array}$ & $\begin{array}{c}\text { Number of } \\
\text { endemic species }\end{array}$ & $\begin{array}{c}\% \text { endemic } \\
\text { species }\end{array}$ & $\begin{array}{c}\text { Number in common } \\
\text { with Macquarie Island }\end{array}$ \\
Macquarie & 21 & $2(+2)^{*}$ & $10(? 20)$ & - & 7 \\
Heard & 8 & 1 & 12 & $7(+2)^{*}$ & 58 \\
Marion & 13 & 2 & 13 & $3(+2)^{*}$ & 33 \\
Kerguelen & 30 & $9(+2)^{*}$ & 29 & $6(+3)^{*}$ & 21 \\
Crozet & 28 & 8 & 30 & - \\
\hline
\end{tabular}

* Species of Sminthurunus and Megalothorax not yet fully determined.

TABLE 6

Biogeographic Affinities of the Macquarie Island Terrestrial Invertebrate Fauna

\begin{tabular}{|c|c|c|c|c|c|}
\hline Taxon & $\begin{array}{c}\text { Number } \\
\text { of } \\
\text { species }\end{array}$ & Cosmopolitan & $\begin{array}{c}\text { Western } \\
\text { subantarctic } \\
\text { islands }\end{array}$ & $\begin{array}{l}\text { New Zealand } \\
\text { subantarctic } \\
\text { islands }\end{array}$ & Unknown \\
\hline Oligochaeta & 8 & 1 & 5 & - & 2 \\
\hline Mollusca & 4 & 1 & - & 1 & 2 \\
\hline Collembola & 31 & 10 & 16 & 4 & 1 \\
\hline \multicolumn{6}{|l|}{ Insecta } \\
\hline Psocoptera & 1 & - & - & 1 & - \\
\hline Thysanoptera & 1 & - & - & 1 & - \\
\hline Heteroptera & 3 & 3 & - & - & - \\
\hline Diptera & 15 & 3 & 2 & 5 & 5 \\
\hline Hymenoptera & 2 & - & - & 1 & 1 \\
\hline Coleoptera & 8 & - & - & 5 & 3 \\
\hline Lepidoptera & 1 & - & - & 1 & - \\
\hline Araneae & 2 & - & 1 & 1 & - \\
\hline Totals & 76 & 18 & 24 & 20 & 14 \\
\hline
\end{tabular}

and two Oligochaeta) with a few others doubtfully endemic (e.g. other Diptera). The Macquarie Island population of Eudonia (Lepidoptera) is distinct probably at less than subspecific level (J. Dugdale, pers. comm.).

This level of endemism is lower than that of Marion Island and the neighbouring Prince Edward Island for which six $(35 \%)$ of the 17 native insect species, excluding Collembola, are endemic (Table 4). The other nine species are classed as naturalised aliens by Crafford et al. (1986). Treated separately, Marion Island and Prince Edward Island each have only one species not occurring on the other. The two islands represent the summits of two extinct volcanoes and are separated by only $20 \mathrm{~km}$. Although Prince Edward Island is only one-seventh the size of Marion Island, they have practically identical faunas. Crafford gives the percentage of insect endemics (excluding Collembola) for Kerguelen, Heard and Crozet Islands of 27, 11 and 67 respectively. Only that of Heard Island, with a small fauna of nine species and one endemic, is less than that of Macquarie Island.

As far as collembolan faunas are concerned, Macquarie Island has a similar level of endemism to Marion Island, which is certainly under-collected, 
but less than half that of Kerguelen and Crozet Islands (table 5). On the whole the Collembola can be taken as characteristic of the invertebrate fauna of Macquarie Island because they are relatively well known and collected and recent revisions are available for the faunas of the Kerguelen group and Heard Is land, as well as for Macquarie Island. Also fairly good information is available for South Georgia, Campbell and Auckland Islands. Therefore, estimates of endemism and species relationships should be relatively reliable for this group. In the past, endemism has been calculated from imperfectly known taxa, which can lead to bias (see Watson 1967, Gressit 1970, Wallwork 1973, Abbott 1974). Collembola represent a high proportion ( $40 \%$ ) of the total number of arthropods, molluscs and oligochaetes excluding mites, from Macquarie Island. The trend in successive calculations of the level of endemism has been towards lowering this figure as faunas become better known taxonom ically (table 2 ).

\section{Affinities}

The taxonomic relationships of the fauna are given in table 6 where the species are grouped as either cosmopolitan or having eastern, western or unknown affinities. The classification is based on where the species or its closest relative occurs outside Macquarie Island. From the totals in table 6 , it appears that the faunal affinities and hence origins lie approximately equally with the western and with the New Zealand subantarctic islands. As far as the insects are concerned, relationships are largely with New Zealand. However, the Collembola and the Oligochacta show affinities to the west, i.e. with subantarctic islands on the opposite side of the antarctic continent. These taxa are more closely associated with the soil than the insects which live for the most part above the soil and litter surface, for at least part of their life cycle, and tend to be more vagile.

From table 6 it can be seen that only four collembolan species have affinities with New Zealand. These are all epigacic, surface, leaf litter or above ground species (L.nawsoni, l.turbotti, P.davidi, K.banzare), while the species with taxonomic affinities to the west, i.e. with other subantarctic islands, live lower in the profile, mostly in humus and soil. A higher proportion of these epigaeic species are predominantly restricted to coastal habitats (three out of four species). Alternatively, two species found almost exclusively on the plateau are both soil dwelling and have affinities with subantarctic islands to the west ( $F$. simplex, (Pseudosorensia) atlantica). In table 5 the relation. ships of Macquarie Island Collembola with those of other subantarctic islands is examined in more detail. The Macquarie Island fauna appears most similar to that of Heard Island, but this is probably because the small fauna of the latter island consists almost entirely of widespread subantarctic species.

\section{DISCUSSION}

When comparing the Macquarie Island fauna with the fauna of the other subantarctic islands, the many variables operating, such as latitude, size, altitude, distance from major land masses, climate, ice free areas etc., have to be considered. Certain common features of their faunas do emerge in spite of those differences and these have been noted by earlier authors (Gressitt 1961, 1962, 1964, 1970, Crafford et al. 1986). All subantarctic islands have small faunas with a disharmonic composition of higher taxa (Carlquist 1974). The same characteristics have been noted for antarctic faunas (Block 1985). However, the level of endemism varies, and on Macquarie Island, from which only one endemic plant is known (P. Selkirk, pers. comm.), the level of endemism appears to be lower than might be expected, given that the island is fairly large, is well vegetated and has an equable climate. Taking into account the trend towards a lower level of endemism with increasing knowledge of the taxonomic affinities of the fauna, it is possible that it may fall even further. One explanation suggests that the ecosystems on the island may be young (Selkirk et al. 1983, Selkirk et al. 1988), having been formed on a raised part of oceanic crust, most of which emerged above sea level perhaps only during the Pleistocene (Williamson 1988), rather than being a relict of an older, once larger land mass. Gressitt earlier suggested a recent origin for the Macquarie Island fauna based on the few wingless insect species that occur there, although he believed the island itself had formerly been part of a larger land mass (Gressit1 1962).

The lack of correlation in the Subantarctic between island area and number of species has been commented on already (Gressitt 1970, Crafford et al. 1986) and it has been said that these faunas provide no support for MacArthur \& Wilson's ( 1967 ) equilibrium theory of island biogeography. Abbott (1974) attempted to find a relationship between the number of insect species (excluding Collembola) occurring on 19 subantarctic and other isolated oceanic islands and their physical and 
biological characteristics. These included area, distance from source area, nearest land to the west, elevation, minimum and maximum temperatures, rainfall, and numbers of plant and bird species. He found no significant correlation between numbers of insect species or any of the measures of isolation, area, latitude or climate. Significant correlations were found between number of insect species and temperature, and he also found that the number of vascular plants can be used to predict the number of insect species. This may simply reflect that plants and insects have similar capacities for dispersal to distant land masses, rather than a direct dependence of insects on plants. Abbott's (1974) comment that area is of minor importance in explaining variation in number of insect species on isolated islands may be due to the fact that when long distance dispersal is involved, the relative ages of the islands are likely to be a more important factor. This does not reduce the validity of the MacArthur \& Wilson (1967) model since these authors stressed that a time factor was involved in determining faunal size as an equilibrium between immigration and extinction.

It is not surprising that the relationship of much of the insect fauna of Macquarie Island is with New Zealand, despite the prevailing wind being from the west. New Zealand and its islands are only $640 \mathrm{~km}$ distant and there are occasional winds from the northeast (Adamson et al. 1988). A parallel distribution pattern is seen, with the fish, where the majority of benthic species have affinities with the western subantarctic region while most pelagic species have distributions in more northerly temperate waters (Williams 1988). The marine and littoral invertebrates, however, show a different pattern. Relationships of shallow water and littoral species are with the circum-subantarctic zone whilst more benthic species show northern or cosmopolitan affinities (Dawson 1988). Although the Rhodacaridae (Acari) of Macquarie Island (Lee \& Hunter 1974) seem to have colonised from New Zealand, other invertebrate taxa, more closely tied to the soil, appear to have originated from the west.

The theory of plate tectonics has contributed to a transformation of our understanding of biogeography and the origins of island faunas. There are still problems, however, regarding islands of recent origin, such as Macquarie Island. Danks (1981) commented that zoogeographical speculation easily outstrips the evidence, and much has been written concerning means of dispersal to isolated islands, particularly of brachypterous species. The ability of these species to disperse is probably underestimated because they can have resistant and/ or dormant life stages. A combination of four factors can explain faunal composition; distance from source area, ease of dispersal of propagule, time and availability of suitable habitat at destination. Limitations of area are not relevant to Macquarie Island at present, because, as has been pointed out by Block (1985) for the Antarctic (and the Subantarctic is similar), invertebrate faunas of subantarctic islands tend to be unsaturated, and habitats contain vacant niches. This is supported by the speed at which introduced species colonise and spread on Macquarie Island (Greenslade \& Wise 1984, 1986). Migration studies indicate that there is a continuous rain of propagules of easily dispersed insects on any area such as Macquarie Island. They can be transported by wind (Close et al. 1978, Washburn \& Washburn 1984, Farrow 1984, Pierrehumbert el al. 1985, Benninghoff \& Benninghoff 1985, Duckhouse 1985, Edwards 1986), drift in currents (Lee 1968, Cheng \& Birch 1978 ) or be brought by man or other animals (Lawrence 1971). Birds have been reported transporting free-living invertebrates (Jamieson 1968) and on Macquarie Island fruits of Acatna magellanica were observed attached to the breast feathers of a skua (P. Greenslade). The fruits can hold large numbers of aphids (Myzus ascallonicus) and occasional other arthropods (P. Greenslade).

Brachyptery is a trait for which a number of different ecological explanations have been offered (Greenslade 1965). Crafford et al. (1986) reviewed the literature and suggested, as did Smithers (1972), that it is paedomorphic in origin. It is known that juvenile hormone prolongs its activity at low temperatures (Wigglesworth 1952) and photoperiod length affects the activity of the corpora allata. The possible physiological causes of brachyptery are discussed by Matsuda (1976). On Macquarie Island less than half the beetles (3), less than one quarter of the flies (3), no moths and the wasp are brachypterous (total 35\%). Of the brachypterous species, only the two Diptera are at present considered to be endemic. Alternatively, in the Prince Edward Island group which includes Marion Island, 15 of the 16 native species are brachypterous, and the percentage of flightless insects is 90 or more in the Kerguelen, Crozet, and Heard Islands. These figures are over three times that of Macquarie Island, which is probably another indication of the relatively recent arrival of the fauna. Brachyptery is characteristic of species found in enviromments where adversity or $\mathbf{A}$ selection is operating (Greenslade 1983). Wing abnormalities are a common feature of inbred populations both in culture and in nature. However, the mechanism by which brachyptery is achieved is not relevant here 
and it is certainly in part a parsimonious response (Downes' 1964 economy of effort) to low biological complexity.

The products of A selection tend to have low reproductive rates, poor dispersal mechanisms, low fecundity and rates of increase, long length of life, late maturity, and slow development (Greenslade 1983). There is selection for parthenogenesis to a variable extent and it has been suggested (Crafford \& Scholtz 1986) that parthenogenetic species are preadapted for subantarctic habitats. Parthenogenesis can also be selected for in habitiats in which $r$-selection occurs. The Macquarie Island fauna carries a high proportion of species which are apparently $r$-selected and which have probably been introduced relatively recently (marked + in check list in the appendix). Some of these species are parthenogenetic, for instance all the Psychodidae and Chironomidae. Edwards \& Usher (1985) have pointed out that antarctic species have a need for flexible life histories, usually a characteristic of $\mathbf{A}$ selection.

The composition of the fauna of Macquarie Island is unlike any other subantarctic island in the lack of curculionids as noted by Gressitt (1970). For instance, on all other subantarctic islands except South Georgia several species of curculionids occur and they are often endemic. Three of the five curculionids in the Marion group of islands are endemic species and one of four on Heard Island (Kuschel 1970). A suitable curculionid habitat of Poa roots in deep peat (a habitat in the Falkland Islands described by Lewis Smith \& Prince (1985) as a "remarkaole" environment) is present in abundance on Macquarie Island. Possible reasons for their absence are the combination of poor dispersal ability and the island's youth. Alternatively, Crafford \& Scholtz (1987) suggested that the absence of a Pringleophaga species (Lepidoptera) on Marion Island, despite its presence on Prince Edward Island and the Kerguelens, could be the result of predation by introduced mice. Mice as well as the insectivorous weka have been present on Macquarie Island since the 19th century and it is possible they have had sone effect on the insect fauna but they are unlikely to have caused extinction of any species, particularly weevils.

The diet of Mus musculus on Macquarie lsland consists mainly of insects (Copson 1986); arachnids, lepidopteran larvae and Diptera have been found in mouse stomachs in that order of abundance. However, even where curculionids are abundant on subantarctic islands they are not eaten to any great extent by mice (Gleeson \& van Rensburg 1982) as the larvae of these insects live in soil and are therefore latgely unavalable to surface-feeding predators. The diet of the weka, which colonised coastal sites only and is now probably eliminatce from Macquarie Island, was studied by Brothers $k$ Skira (1984). Inventebrates were found in nearly all stonich contents examined and included kelp tlics spiders, and lepidopteran larvae. In addition, the cxtent to which the type and abundance of invertebrates has been affected by mave inseci ivorous birds on the island is unkmown but could have been signilicant.

As the only remaining indigenous land animals of Macquarie Island (wwo terrestrial bird species became extinct beforel900), invertebrates are significant members of the biona and are key elements in food webs (Burger 1985). Aboveground herbivory is low on subantarctic islands (Crafford et al. 1986), and so the soil and litter fauna is more important in nutrient cycling here than in more temperate climates. With the possibility of climatic amelioration (Adamson et al. 1988), it might be expected that the rate of colonisation by exotic species will increase. Taking the Collembola as an example, a third of the species now found on the island have almost certainly been relatively recently introduced by man and half of these have become naturalised. Some changes might be expected in trophic roles and in the cycling of organic matter (both on the island and between the terrestrial and marine ecosystems by means of marine invertebrates) as a result of changes in the decomposer organisms present.

\section{EPILOGUE}

"The ward-room is the battle field of more scientific thrills. The dining-table resembles a section of richly verdured. South Georgian terrain. Sir Ernest Shackleton, Jock Wordie, Robbie Clark, Hussey, Dr Macklin and one or two helpers, armed with forceps and magnifying lenses, bend over a heterogenous profusion of grasses, mosses, lichens, azorellas, etc. They are searching the tangled mass, blade by blade and leaf by leaf, for tiny springtails, diminutive spiders, beelles, slaters, and other lowly insects. Though I sympathize with the scientists, I am afraid I have not the patience to enthuse over these microscopical 'bug hunts'. Evidently they stimulate in the scientific mind some highly specialized emotion which I lack. However, I admire the zeal and indefatigable patience of these learned men." (Nurley 1979.) 


\section{ACKNOWLEDGEMENTS}

The author is grateful to the Tasmanian Department of Parks, Wildlife and Heritage for permission to collect on Macquarie Island, to the Australian Antarctic Division for logistic support with fieldwork and to the Australian Antarctic Science Advisory Committee Grants Scheme for financial support white working on the Macquarie Island fauna.

\section{REFERENCES}

Aввотт, I., 1974: Numbers of plant, insect and land bird species on nineteen remote islands in the Southern Hemisphere. Biol. J. Linn. Soc. 6: 143-152.

Adamson, D.A., Whetron, P. \& Selkirk, P.M. 1988: An analysis of air temperature records for Macquarie Island: decadel warming, ENSO cooling and southern hemisphere circulation patterns. Pap. Proc. R. Soc. Tasm. 122(1): 107-112.

Alexander, C.P., 1962: Insects of Macquarie Island, Diptera: Tipulidae. Patif. Insects 4(4): 939-944.

Bakker, E.M. VAN Z., SR, Winterbottom, J.M. \& Dyer, R.A. (Eds), 1971: MARION AND PRINCE EDWARD ISLAND. A.A. Balkema, Capelown.

BALL, I.R. \& HAY, D.A., 1977: The taxonomy and ecology of a new monocelid flatworm from Macquarie Island (Platyhelninthes: Turbellaria). Bijdragen tot de Dierkunde 47: 205-214.

Benninghoff, W.S. \& Benningihor, A.S., 1985: Wind transport of electrostatically charged particles and minute organisms in Antarctica. In Siegfricd, W.R., Condy, P.R. \& Laws, R.M. (Eds): ANTARCTIC NUTRIENT CYCLES AND FOOD WEBS. Springer-Vcrlag, Berlin.

BLock, W., 1984: Terrestrial microbiology, invertebrates and ecosystems. In Laws, R.M. (Ed.): ANTARCTIC ECOLOGY I. Academic Press, London: 163-236.

Brock, W., 1985: Arthropod interactions in an Antarctic terrestrial community. In Siegfried, W.R., Condy, P.R. \& Laws, R.M. (Eds): ANTARCTIC NUTRIENT CYCLES AND FOOD WEBS. Springer-Verlis, Berlin: 614-619.

Bock, I.R., 1987: '? Australian species of Ephydrella and Setacera (Diptera: Ephydridae). Invertebr. Taxon. 1: 155-166.

Brothers, N.P. \& SkIRA, I.J., 1984: The weks on Macquaric Island. Notomis 31: 145-154.

BrLndr, L., 1962: Insects of Macquarie island: Diptera: Chironomilae. Pacif. Insects 4(4): 945-954.

BunT, J.S., 1954: The soil-inhabiting nematodes of Macquarie Island. Aust. J. Zool. 2: 264-274.

Burger, A.E., 1985: Terrestrial food webs in the Subantarctic: island effects. I $n$ Burton, D.W., 1963: A revision of the New Zedand and Subantarctic Athoracophoridac. Trans. R. Soc. N.Z, 3(6): $47-75$.
Burton, D.W., 1963: A revision of the New Zealand and Subantaretic Athoracophoridae. Trans. R. Soc. N.Z. $3(6): 47-7.5$.

BLRTON, D.W., 1980: Anatomical studies on Australian, New Zealand and subantarctic Athoracophoridae (Gastropoda: Pulmonata). N.Z. J. Zool. 7 : $173-198$.

Carlolist, S., 1974: ISLAND BlOLOGY. Columbia University Press, New York.

Cheno, L. \& Brker, M.C., 1978: Insect flotsim: in unstudied marine resource. Ecol. Entomol. 3: $87-97$.

Close, R.C., Moar, N.T., Tomlinson, A.I. \& Lowe, A.D., 1978: Aerial dispersal of biological material from Australia to New Zealand. Int. J. Biometeor. 22(1): $1-19$.

Common, 1.F.B., 1962: Insects of Macquarie Island, Lepidoptera: Pyralidae: Scopariinae). Pacif. Insects 4(4): 975-978.

Copson, G.R., 1986: The diet of the introduced rodents Mus musculus L. and Rattus rattus L. on subantarctic Macquarie Island. Aust. Wildl. Res. 13: $441-445$.

CRAFFORD, J.E., 1984: Life cycle and kelp consumption of Paractora dreuxi mirabilis (Diptera: Helcomyzidae): a primary decomposer of stranded kelp on Marion LsIand. S. Afr. J. Antarct. Res. 14: 18-22.

Crafford, J.E., 1986: A case study of an alien invertebrate (Limnophyes pusillas, Diptera, Chironomidae) introduced on Marion Island: selective advantages. S. Afr. J. Antarct. Res. 16: 1.15-117.

Crafford, J.E. \& ScholTz, C.H., 1987: Quantitative differences between the insect faunas of subantarctic Marion and Prince Edward Islands: a result of human intervention? Biol. Conserv. 40: $255-262$.

Crafford, J.E., Scholtz, C.H. \& Chown, S.L., 1986: The insects of subantarctic Marion and Prince Edward Islands; with a bibliography of entomology of the Kerguelen biogeographical province. $S$. Afr. I. Antarct. Res. 16: 41-84.

CSIRO, 1970: THE INSECTS OF AUSTRALIA. Melbourne University Press, Australia.

DANks, H.V., 1981: The composition, distribution and ecology of Arctic insects, with some speculations on the evolution of Arctic communities. In Scudder, G.G.E. \& Reveral, J.L. (Eds): EVOLUTION TODAY. Proc. 2nd Int. Congr. System. Evol. Biol:: $21-23$.

Dawson, E.W., 1988: The offshore fauna of Macquarie Island: history and biogeography -..- results from New Zealand and United States Research Cruises. Pap. Proc. R. Soc. Tasm. 122: 219-232.

Denarvenc, L., 1981: Collemboles des îles subantarctiques de l'Océan Indicn. Biologie des Sols Comiré National Français des Recherches Antarctiques 48: 33-108.

DeLi, R.K., 1964: Land snails from subantarctic islands. Trans. R. Soc. N.Z., Zool. 4(11): 167-173. 
Dowses, J.A., 1964: Arctic insects and their environment. Can. Ent. 10: 257-274.

Decknouse, D.A., 1970: Diptera: Psychodidae of South Georgia. Pacif. Insects Monogr. 23: 283.

Dickhouse, D.A., 1971: Entomology of the Aucklands and other islands south of New Zealand: Diptera: Psychodidae. Pacif. Insects Monogr. 27: 317-325.

Duckholse, D.A., 1985: Psychodidae (Diptera, Nenatocera) of the Subantarctic Islands, with observations on the incidence of parthenogenesis. Int. J. Ent. 27(3): 173-184.

EARIY, J., 1978: New Diaprinae (Hymenoptera: Diapriidae) from the South lsland and Subantarctic Islands of New Zealand. $I . R$. Soc. N.Z. $8(2)$ : $207-228$.

EArty, J., 1980: The Diapriidae (Hymenoptera) of the Southern Islands of New Zealand. I. R. Soc N.Z. 10(2): 153-171.

EAstop, V.F., 1962: Insects of Macquarie Island. Hemiptera: Homoptera: Aphididae. Pacif. Insects 4(4): 937-938.

Eastop, V.F., 1970: Hemiptera: Homoptera: Aphidae of South Georgia. Pacif. Insects Monogr. 23: 277.

Enwards, J.S., I986: Derelicts of dispersal: arthropod fall out on Pacific North West volcanoes. In Danthanarayan, W. (Ed.): INSECT FLIGHT: DISPERSAL AND MIGRATION. SpringerVerlag, Berlin: 196-203.

Edwards, M. \& Usher, M.B., 1985: The winged Antarctic midge Parachius steinenii (Gerke) (Diptera: Chironomidae) in the South Shetland Islands. Biol. J. Linn. Soc. 26: 83-93.

Evenhuis, N.L., 1989: Appendix 1. Diptera of Antarctic and Subantarctic Islands. In Evenhuis, N.L. (Ed.): CATALOGUE OF OCEANIC AND AUSTRALASIAN DIPTERA. Bishop Museum Press. Honolulu and E.J. Brill, Leiden: 797-804.

FARROW, R., 1984: Detection of transoceanic migration of insects to a remote island in the Coral Sea, Willis Island. Aust. . Ecol. 9: 253-272.

ForSTER, R.R., 1955: Spiders from the subantarctic islands of New Zealand. Rec. Dom. Mus. 2(4): 167.

FORSTER, R.R., 1962: Insects of Macquarie Island Araneida (Spiders). Pacif. Insects 4(4): $917-919$

Forster, R.R., 1970: The spiders of New Zealand. Part III. Desidae, Dictynidae, Hahniidac, Amaurobiodidac, Nicodamidae. Otago Mus. Bull. 3: $1-184$.

FORSTER, R.R. \& Blest, A.D., 1979: The spiders of New Zealand. Part V. Lynyphiidae - Mynogleninae. Otago Mus. Bull. 5: 1-173.

Gleeson, J.P. \& van Rensburg, P.J.J., 1982: Feeding ecology of the house mouse Mus musculus on Marion lsland. S. Afr. J. Antarkt. Res. 12: 34-39:

Greesslade, P., 1985: The Conservation Status of Tasmanian Non-Marine Invertebrates. Unpubl. rep. Tasm. Nat. Pks Wildl. Serv.

Greenslade, P., 1986: Additions to the collembolan fauna of Heard Island. Rec. S Aust. Mus. 19:91-96.

Greenslade, P., 1987a: Zoogeography of Tasmanian Collembola genera. In SOHL FAUNA AND SOIL
FERTLITY, Proc. VI Colloq. Apterygua Moscow. 1985: 653-660.

GreEnSLADE, P., 1987b: Invertebrate conservation in the Antarctic and Subantarctic. In Majer, J.D. (Ed.) THE ROLE OF INVERTEBRATES IN CONSERVATION AND BIOLOGICAL SURVEY W.A. Dep. Cons. Land Manage. Rep.: 119-121.

Greenslade, P. \& Wise, K.A.J., 1984: Additions to the collembolan fauna of the Antarctic. Trans. R. Soc S. Aust. 108: 203-205.

Greenslade, P. \& Wise, K.A.J., 1986: Collembola of Macquarie Island. Rec. Auckl. Inst. Mus. 23: $67-97$.

Greenslade, P.J.M., 1965: Habitat and attitude distribution of Carabidae (Coleoptera) in Argyll, Scotland. Trans. R ent Sor l.ond 23A, 120(2): $39-54$.

Greenslade, P.J.M., 1983: Adversity selection and the habitat templet. Am. Nat. 122(3): 353-365.

Gressitr, J.L., 1961: Problems in the zoogeography of Pacific and Antarctic insects. Parif. Insects Monogr. 2: 1-94.

Gressitt, J.L., 1962: Insects of Macquarie Island. Introduction. Pacif. Insects 3(4): 905-915.

Gressitt, J.L., 1964: Insects of Campbell Island. Pacif. Insects Monogr. 7: 1-663.

Gressitt, J.L., 1970; Subantarctic entomology, particularly of South Georgia and Heard Island. Pacif. Insects Monogr. 23: i-iv, 1-374.

HAMOND, R., 1987: Non-marine harpacticoid copepods of Australia. I. Canthocamptidae of the genus Canthocamptus Westwood s. lat. and Fibulacamptus gen. nov., and including the description of a related new species of Canthocamptus from New Caledonia. Invertebr. Taxon. 1: 1023-1247.

Harrison, R.A., 1959: Acalypterate Diptera of New Zealand. N.Z. DSIR Bull. 128: 382 pp.

HARRISON, R.A., 1976: The arthropoda of the southern islands of New Zealand. (9) Diptera. J. R. Soc. N.Z. 6(2): 107-152.

Hedley, C., I916: Mollusca. A.A.E. Sei. Rep., Ser. C 4(1): $1-80$.

Hickman, V.V., 1939: Opiliones and Araneae. BANZARE Rep. Ser. B4(5): 157-188.

HuRLEY, F., 1979: SHACKLETON'S ARGONAUTS. THE EPIC TALE OF SHACKLETON'S VOYAGE TO ANTARCTICA IN 19I5. McGraw-Hill Book Co., Sydney.

JAMRESON, B.G.M., 1968: Macquaridrilus: a new genus of Tubificidae (Oligochaeta) from Macquarie Island. Univ. Qld Pap. 3(5): 55-69

Jeannfi, R., 1940: III Coléoptères. In Jeannel, R. (Ed.): Croisière du Bougainville aux îles Australes Françaises. Mém. Mus. Hist nat. 14: 63-201.

Kuschel, G., 1970: Coleoptera: Curculionidae of Heard Island. Pacif. Insects Mon. 23: 255-260.

LAwrence, R.F., 1971: Araneida. In Bakker, E.M. van Z., Sr., Winterbottom, J.M. \& Dyer, R.A. (Eds): MARION AND PRINCE EDWARD ISLANDS. A.A. Balkema, Capetown: 301-313.

LEe, D.C. \& Hunter, P.E., 1974: Arthropoda of the 
subantarctic islands of New Zealand. 6. Rhodacaridae (Acari: Mesostigmata). N.Z.J.Zool. 1(3): $295-328$.

LEE, K.E., 1959: The carthworm fauna of New Zealand. N.Z. DSIR Bull. 130: $1-486$.

LeE, K.E., 1968: Oligochaeta from subantarctic islands. BANZARE Rep. Ser. B8(8): 149-165.

Lewis SMITh, R.I. \& Prince, P.A., 1985: The natural history of Beauchêne Istand. Biol. J. Limn. Soc. 24: $233-283$.

MacArthur, R.H. \& Wilson, E.O., 1967: THE THEORY OF ISLAND BIOGEOGRAPHY. Princeton Universily Press, Princeton, N.J.

McQuillan, P.B. \& Marker, P., 1984: The kelpnlies (Diptera: Coelopidae) of Macquarie Island. Tasm. Nat. 79: 17-20.

Mathis, W.N., 1989: Coelopidae. In Evenhuis, N.L. (Ed.): CATALOGUE OF OCEANIC AND AUSTRALASIAN DIPTERA. Bishop Museum Press, Honolulu and E.J. Brill, Leiden: 563-564.

MATSUDA, R., 1976: MORPHOLOGY AND EVOLUTION OF THE INSECT ABDOMEN WITH SPECIAL REFERENCE TO DEVELOPMENTAL PATTERNS AND THEIR BEARINGS UPON SYSTEMATICS. Pergamon, Oxford: 1-534.

Mound, L.A. \& WALKER, A.K., 1982: TEREBRANTIA (INSECTA: THYSANOPTERA). FAUNA OF NEW ZEALAND 1. Wellington, New Zealand: II 3 pp.

Newton, A.F., 1985: South temperate Staphylinoidea (Coleoptera): their potential for biogeographic analysis of austral disjunctions. In Ball, G.E. (Ed.): TAXONOMY, PHYLOGENY AND ZOOGEOGRAPHY OF BEETLES AND ANTS. Junk, Dordrecht: $180-220$.

Pierrehumbert, C.P.H., Powell, F.A. \& Oliver, S., 1985: Continental transport of particulate matter between Australia and Macquarie Island. Proc. 8th Int. Clean Air Conf., Melbourne, 1984: $741-750$.

Quate, L.W., 1962: Insects of Macquarie Island. Diptera: Psychodidae. Pacif. Insects 4(4): 958.

Rainbow, W.J., 1917: Arachnida from Macquarie Island. AAE Sci. Rep., Ser. C5(1): 1-13.

Ramazzoti, G. \& Malici, W., 1983: IL PHILUM TARDFGRADA. III. Elizione Rivedura e Aggiornata Memoire dell Instituto haliano di Idrobiologia, Verbania Pallanza, Italy: $1012 \mathrm{pp.}$

SABRosky, C.M. I's2: Insects of Macquarie Island. Diptera: Chloropidae, Milichiidae. Pacif. Insects 4(4): 973.

Salmon, J.T., 1964: An inctex to the Collembola. Bull, R. Soc. N.Z. 7: 651 pp.

Séruy, E., 1940: IV Diptères. In Jeannel, R. (Ed.): Croisière du Bougainville aux Ĵles Australes Françaises, Mém. Mus. Hist nat. 14: 203-267.

Selkirk, D.R., Selkirk, P.M. \& GriffiN, K., 1983 : Palynological evidence for Holocene environmental change and uplift on Wircless Hill, Macquarie Island. Proc. Linn. Soc. NSW 107: $1-17$.
SFikiRk, D.R., SElKirk, P.M. \& SEPpFl, R.D., 1986: An annotated bibliography of Macquarie Island. ANARE RES. Notes 38: $1-134$.

Selkirk, D.R., Selkirk, P.M., Bergstrom, D. \& ADAMSON, D.A., 1988: Ridge top peats and palacolace deposits on Macquarie Island. Pap. Proc. R. Soc Tasm. 122(1): 83-90.

Selkikk, P.M., Slappelt, R.D. \& Selkirk, D.R., 1990 : SUBANTARCTIC MACOUARIE ISIAND. ENVIRONMENT AND BIOLOGY. Cambridge University Press.

Sims, R.W., 1971: Oligochacta. In Bakker, E.M., van Z., Sr., Winterbottom, J.M. \& Dyer, R.A. (Eds): MARION AND PRINCE EDWARD TSLANDS. A.A. Balkema, Capetown: 391-393.

Smirnov, N.N. \& Timms, B.V., 1983: A revision of the Australian Cladocera (Crustacea). Rec. Aust. Mus., Supp. 1: 1-132.

Smithers, C.N., 1964: Insects on Campbell Island. Psocoptera. Pacif. Insects Monogr. 7: 226-229.

Smithers, C.N., 1972: The classification and phylogeny of the Psocoptera. Mem. Aust. Mus. 14: 1--349.

Steel, W.O., 1964: Insects of Campbell Island. Coleoptera: Staphylinidae. Pacif. Insects Monogr. 7: 340-375.

STEEl, W.O., 1970: Coleoptera: Staphylinidae of South Georgia. Pacif. Insects Monogr. 23: 240-242.

Sublette, J.E. \& WIRTH, W.W., 1980: The Chironomidae and Ceratopogonidae (Diptera) of New Zealand's subantarctic islands. N.Z. J. Zool. 7: 299--378.

THornton, J.W.B., 1985: The geographical and ecological distribution of arboreal Psocoptera. Ann. Rev. Entomol. 30: 175-196.

WALLWORK, J.A., 1973: Zoogeography of some terrestrial micro-arthropoda in Antarctica. Biol. Rev. 48: 233-259.

Washburn, J.O. \& Washburn, L., 1984: Active aerial dispersal of minute wingless arthropods: exploitation of boundary layer velocity gradients. Science 233: 1088-1089.

Watson, K.C., 1967: The terrestrial Arthropoda of Macquarie Island. ANARE Sci. Rep. Ser, B(I), 99: 90 .

WAIT, J.C., 1971: Entomology of the Aucklands and other islands south of New Zealand: Coleoptera: Scarabaeidac, Byrrhidae, Ptinidae, Tenebrionidae. Pacif. Insects Monogr, 27: 193-224.

Wigglesworth, V.B., 1952: Hormone balance and the control of metamorphosis in Rhodnits prolixus (Hemiptera). J. Expl. Biol. 29: 620-631.

WILliams, R, 1988: The nearshore fishes of Macquarie Island. Pap. Proc. R. Soc. Tasm. 122(1): 233--245.

Willamson, P.E., 1988: Origin, structural and tectonic history of the Macquarie Island region. Pap. ProC. R. Soc. Tasm. 122(1): 27-43.

Wrse, K.A.J., 1977: A synonymic checklist of the Hexapoda of the New Zealand sub-region. The smaller orders. Bull. Auckl. Inst. Mus. 11: 1-176.

Womersley, H., 1937a: Acarina. AAE Sci. Rep., Ser. $C / 0(6): 1-241$. 
WomersleEy, H., 1937b: Coleoptera. BANZARE Rep., Ser $B 4(\mathrm{l}): 23-26$.

WOMERSLEY,H., 1937c: Collembola, BANZARE Rep.. Ser. B4(1): $1-7$.
Womersley, H., 1937d: Diptera. BAN7ARl Rep., Ser $B 4(3): 59-79$.

Yoshimoto, C.M., 1962: Insects of Macquarie Island. Hymenoptera: Diapridae. Pacif. Insects 4(4): 973-974.

\section{APPENDIX \\ Annotated Checklist of Free-living Terrestrial Invertebrates of Macquarie Island}

* new record (localities given)

$\dagger$ endemic species

\# species recorded earlier from Macquarie Island but probably misidentified

\section{OLIGOCHAETA \\ MEGASCOLECIDAE}

Microscolex macquariensis (Beddard 1896) +

Considered to be endemic to Macquarie Island (Lec 1959. 1968) and, according to Lee, most closely related to species from South Georgia and the Kerguelen Islands, but also close to a species in Campbell Island. Sims (1971) states that this species may only be a geographical race and not a full species.

\section{LUMBRICIDAE}

Bimastus tenuis (Eisen 1874)

Recorded by Lee (1968) and also known from Kerguelen and Heard Islands; a cosmopolitan species.

\section{TUBIFICIDAE}

Macquaridrilus bennettae Jamieson $1968+$

An endemic species of a monotypic genus. It is considered to be an ancestral form of obscure relationships and may have reached the island only recently (Jamieson 1968).

\section{ENCHYTRAEIDAE}

Enchytraeus albidus Henle 1837

Also known from the Kerguelen and Crozet Islands; recorded from Macquarie Island by Lee (1968) from a determination by L. Cernosvitov; occupying marine, limnic and terrestrial habitats. One of the commonest species in the family.

Pachydrilus macquariensis (Benham 1915) =

Lumbricillus macquariensis Benham 1915 व

Also known from Heard Island. Recorded by Lee (1968) from a determination by $\mathrm{L}$. Cenosvitov.

Pachydrilus maximus Michaelsen 1900 9

Also known from Heard Island and the Kerguelens. Recorded by Lee (1968) from a detcrmination by L. Cernosvitov.

Pachydrilus werthi $($ Michaelsen 1905) = Lumbricillus werthi (Michaelsen 1905) 1

Marionina antipodum (Benham 1905) q native (indigenous)

$\$$ introduced and naturalised

$\S$ introduced and not naturalised

\section{MOLLUSCA \\ ATHORACOPHORIDAE \\ Reflectopallium martensi (Suter 1909) $9=$ \\ Athoracophorus (Amphiconophora) maitensi Suter 1909}

Also occurs on Auckland Island. An indigenous species according to Watson (1967) but not recorded by Dell (1964). Burton (1963) erected the genus Reflectopallium and gave the Auckland Islands as the locality but subsequently mentioned a Macquarie Island locality ( $p$. 73). In a later publication (Burion 1980) he added a further discussion of the species.

Pseudaneitea huttoni (Suter 1909) if =

Athoracophorus (Pseudaneitea) huttom Suter 1909

Also occurs on The Snares. An indigenous species according to Watson (1967) but not recorded by Dell (1964). Burton (1963) did not give a Macquarie Island locality.

\section{LIMACIDAE}

Deroceras reticularis Müller $1774+=$ Agriolimax agrestis Linné sensu Hedley 1916

According to Hedley (1916), this European slug has been introduced and was first found around sealers' huts at Lusitania Bay. It is the commonest British slug and has a cosmopolitan distribution. Dell (1964) commented that it is now well established.

\section{PUNCTIDAE}

Phrixgnathus hamiltoni Suter $1896 \%=$ Laoma (Phrixgnathus) hamiltoni Suter $1896=$ Phrixgnathus hamiltoni Hedley 1916? = Laoma campbellica Hamilton 1894 (misidentification)

According to Hedley (1916), this snal was the "southernmost in the world", but molluses have now been recorded from terrestrial habitats on Heard, Possession, the Kerguelen, Marion, and South Georgia (Cumberland Bay East) Islands (Block 1984). Dell (1964) considered that this species is very close to an inadequately described species from Campbell Island, Phrixgnathus cambellica 
(Filhol). Affinites of this species are definitely with New Zealand. F. Climo (pers. comm.) considers the Campbell, Auckland and Macquarie specimens to be conspecific although the species is morphologically variable.

\section{TARDIGRADA}

\section{MACROBIOTIDAE}

Pseudobiofus augrasti (Murray 1907) I?

Probably a commopolitan species (Ramazoli \& Maucci 1983). Several other tardigrade species have been collected, permaps as many as 40 , but records have not yet been published. Nearly all appear to be widely distributed (D. Horning, pers. comm.).

\section{ARTHROPODA}

\section{COLLEMBOLA}

\section{HYPOGASTRURIDAE}

Hypogastrura (Hypogastrura) purpurescens

(Lubbock 1868) \%

Hypogastrura (Hypogastrura) viatica (Tullberg

1872) $\div$

Hypogastrura (Ceratophysella) denticulata (Bagnall 1941) $\div$

These three species are cosmopolitan and H. purpurescens and $H$. denticulata have probably been introduced recently (Greenslade \& Wise 1984, 1986).

NEANURIDAE

Friesea tibrooki Wise 1970 औ = Friesea wienne?

Deharveng 1981

Also known from Heard Island and Bouvetoya (Greenslade 1986, Greenslade \& Wise 1986).

Friesea simplex Cassagnau \& Rapoport 1962 I*

Otherwise only known from the Tucuman district of Patagonia (Deharveng 1981). Locality: Plateatu, in Azorella, 1986-87.

\section{ONYCHIURIDAE}

Tulbergia bisetosa Börner 1902 ॥

Tulbergia remplei Wise 1967 ॥

Both these species are widespread in the Subantarctic (Greenslade 1986, Greenslade \& Wise 1986).

Mesaphorara sp. kratwhaneri group Börner 1901 \& An introduced European species which has only been found so far in the Macquarie Island station greenhouse; also known from Australia (Grcenslade 1987b).

Protaphorara fimatus (Gisin 1952) \$

Only recorded so far in the greenhouse (Greenslade 1987b); also known from Furope in compost. Nnother species in the genus was recorded as infroduced to Deception Island (Greenslade \& Wise 1984).

\section{ISOTOMIDAF:}

Archisotoma brucei (Carponter 1907) sensh Poinsot 1965 q $^{*}$

Also known from Auckland lsland Salmon, identification not confirmed) and Signy Island (new record, $P$. Greenslade). Iocality: Hassethorough Bay, Buckles Bay. lsotoma (Parisotoma) insularis Deharveng 19819 ? Also from Crozet lstand. The Macquarie Istand specimens have some differences from those from Croyet Island and may subsequently prove to be a different species.

Isotoma (Folsomotoma) punctata Wahlgren 1902 ! Widespread in the Subantarctic region. Not on Aucklant or Campbell islands, where a different Folsomotomiz specios occurs.

Isotoma (Desoria) tigrina Nicolet 1842 +

An introduced European species also known from Australia.

Isotoma (Pseudesorensia) sp. ct. atlantica (Wise 1970) ?

This species may be new and possibly endernic; further taxonomic studies are required.

Cryptopygus antarcticus antarcticus Willem 1901 in

A common species of the Antarctic and Subantarctic. Cryptopygus dubius Deharveng 1981 \%

Also known from Marion Island. Cryptopygus caecus Wahlgren 1900 I

A very widespread species and native to the Southern Hemisphere.

Cryptopygus lawrencei Deharveng 1981 ॠ

Also known from Kerguelen Island.

Cryptopygus tricuspis Enderlein 1909 ?

Widespread in the Subantarctic (Greenslade 1986 , Grecnstade \& Wise 1986).

Proisotoma minuta (Tullberg 1871) \&*

Only known from the station greenhouse, but a common widespread species with numerous records from Australia in disturbed habitats.

Isotoma tumboti Salmon 1949 q?*

This species was described from Auckland Island. Locality: Green Gorge.

ENTOMOBRYIDAE

Lepidobrya mawsoni (Tillyard 1920$)=*$ Lepidobrya aurantica Salmon 1949 syn. nov. If (Taxonomic justification for synonymies to be published - P. Greenslade, in prep.)

Also known from Campbell and Auckland Islands. This species was previously thought to be endemic to Maequaric (Womersley 1937c).

lepidocytus sp. lignorum group nr. violaceus Geofroy 1762 ;

Previously recorded under the names of Lepidocytus cyoneas cinereas folsom 1924 and Lepidosira terraeregina Ellis \& Bellinger 1973 (Grecnslade \& Wise 1986). These identifications were made by Salmon (Watson 1967) based on fow and poor specimens. More material is avajable now and all Macquarie Istand Lepidocyrtini collected belong to the same species. Acoording to $\mathrm{W}$. Hither (pers. comm.) the specimens are dissimilar to all foms from Europe so far examined by him. 


\section{SMINTHURIDAE \\ Sminthurides spo malmgreni (Tulberg 1876) groups*}

Only known from the greenhouse, and belonging to a species group recorded rom southern South Austailia, close to a species from Kangaroo lsland.

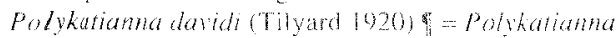
gressitti (Samon 1964) wh not = Polkatiamk

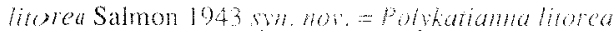
lateaterga Silmon 19.43 sym. hon. Taxonomic justification for synonymies to be published - $P$ Greenslade, in prep.)

This species, previously thought 10 be endemic to Macquarie Island (Womersley 1937c), is now known from Campbell Island, Auckland Island and mainland New Zealand.

Sminthurinus kerguelenensis sensu Salmon 1964 \#

Also known from the Kerguelens. This species was identified from Macquarie Island by Salmon (1964) from an immature specmen but was probably a misidentification.

?Sminthurinus sp. cf. terrestris Womersley 1931 q?t Collected sporadically from coastal sites.

Sminthurinus quadrimuculatus (Ryder 1879) \&

Only known from the greenhouse (Greenslade 1987b) and previously only recorded from North America

Sminthurinus sp. cf tuberculatus Delamare \& Rapoport 1963 月*

Also known from southern South America. Various collections from the Plateau and from coastal sites.

Sminthurinus sp. nr granulosus Enderlein 1909 q?* Also recorded from the Crozet, Kerguelen and Marion Islands (De Harveng 1981). Only immature specimens are available so a definite identification cannot be made. Locality: Poa on platean, above Hasselborough Bay $c$. $250 \mathrm{~m}$.

Katianna banzare Salmon 1964 i

At present this species is only known from Macquarie lskand and may be endemic, although some unidentified immature Katianna species have been seen from Campbell Island and are known from the Kerguelens and The Snares. NEELIDAE

Megalothorat sp. or spe. fi?

Not identitied as the genus is poorly known worldwide.

\section{INSECTA}

PSOCOPTERA: PHILOTARSIDAE

Austropsocus insularis Smithers 1962 q

Recorded by Watson (1967) as endemic but since recorded from the Antipodes, The Snares, Camphell and Auckland Islands (Smithers 1964, Wise 1977). The genus has several species in New Zealand (Thornton 1985). Winged.

\section{HEMIPTERA: APHIDIDAE}

Jacksonia papillata Theobald $1923+$

This species occurs in Europe and New Zealand (Eastop 1962, 1970), but is apparently absent from Australia. In Europe it appears to prefer cool, humid climates (M. Carver, pers. comm.).
Rhopalosiphm pali (Linnates 1758) 主

This species has a cosmopoltan distribution, but is rare on Macquarie lsland.

Mrats ascalonicus Doncaster $1946 t^{*}$

Again, this species is rate in Australia but currently very common on Macquarie Island; large numbers were found in green Acana seed hoads. I1 was first identified from Macquarie Islund by M. Carver in 1975 (M. Carver, pers. comm.) but was not collected by Watson in 1960 , hentes maly be a recent introduction.

\section{THYSANOPTERA: THRIPIDAE}

Physemothrips chysodermus Stannard 1962 I According to Watson (1967) this species is known only from Macquarie Istand but Mound \& Walker (1982) record it also from Auckland Island. A darker form was collected on Macquarie in Azorella (L. Mound, pers. comm.).

\section{COLEOPTERA: STAPHYLINIDAE}

OMALIINAE

Omaliomimus albipenne (Kiesenwetter 1877)

Omalium albipenne Kiesenwetter $1877=$ Omalium

variipenne Lea 1920 nec Womersley $1937=$

Omaliomimus flavipenis Cameron 1947

Also known from Auckland and Campbell Islands (Jeannel 1940, Gressitt 1970); a wingless species.

Omaliominus venator (Broun 1909) 의

Omalium venator Broun 1909

Also known from Auckland and Campbell Islands (Stecl 1964, Watson 1967, Gressitt 1970); a wingless species.

Stenomalium helmsi (Cameron 1945) \&

Onalium helmsi Cameron 1945

Also known from New Zealand (Watson 1967, Gressitt 1970); winged and often found on carrion (M. Thayer, pers. comm., Newton 1985 as Omalinae Genus E).

Stenomalium sulcithorax (Broun 1880)ी

Omalium sultithorax Broun $1880=$ Omalium

perplexum Broun 1894=Homalium variipenne sensu Womersley 1937 nec Lea 1920

Watson (1967), in publishing this synonymy, quoted W.O. Steel's unpublished opinions that the specimens studied by Womersley (1937b) and identified by him as $A$. crozentensis Enderlcin were neither that species nor $H$. varipenne Lea but were conspecific with $O$. perplexum Broun. The species is winged and known from carrion. Also found in New Zealand.

Crymus sp. = Arpediomimus sp.

Recorded by Siecl (1964:349, M. Thayer, pers. comm.), wings vestigial.

Homalium briipenne. Tillyard 1920, nec Lea 1920 Probably a larva of uncertain identification (M. Thayer, pers. comm.).

\section{ALEOCHARINAE}

Halmaeusa antartica Kiesenwetter $1877=$

Antarctophytosus macquariensis Womersley 1937 Also known from Auckland Istand (Steel 1964, 1970 , Watson 1967). The species is wingless and terrestrial.

The Staphylinidae (Omalinae) are currently being studied by $\mathrm{M}$. Thayer. 


\section{BYRRHIDAE}

Epichorius surenseni (Brookes 1951) I

Only one adult, one pupa and some larvae known (Watson 1967), identified by Watt (1971). Also known from Campbell Island.

\section{DIPTERA: TIPULIDAE}

Erioptera (Trimicra) pilipes macquariensis

Alexander $1962=$ Trimicra pilipes Fabricius 1787 The nominate species is cosmopolitan. This may be a variety rather than a subspecies as interpreted from Watson (1967) and P. Johns (pers. comm.). The species is known to be variable (P. Johns, pers. comm.), and Macquarie Island specimens exhibit much morphological variation (Alexander 1962) which is within that of Campbell Island and New Zealand populations (P. Johm, pers. comm.). A winged species.

\section{PSYCHODIDAE}

Psychoda surcoufi Tonnoir $1922=$ Psychoda spatulata Satchell $1950=$ Psychoda subimmaculate Tonr. sensu Womersley $1937 \ddagger$

This species is also known from New Zealand (including Campbell, Auck land and the Antipodes Islands), southern Australia and southern South America (Duckhouse 1985). Psychoda parthenogenetica Tonnoir $1940 \ddagger$

Psychoda severini parthenogenetica Tonnoir 1940

A species restricted to Europe, Africa, Japan, Australia and New Zealand (Duckhouse I970, 1971, 1985, Watson 1967) and known also from Crozet, Marion, South Georgia and Kerguelen Islands.

Psychoda alternata Say $1824 \&$

There is only a single record of this cosmopolitan species from Macquarie Island (Quate 1962) and this species is probably not a permanent resident of the island (Duckhouse 1985).

\section{CHIRONOMIDAE}

Telmatogeton macquariensis (Brundin 1962) = Helirytus macquariensis Brundin $1962 \dagger$

An cndemic species according to Watson (1967). Brundin (1962) said it is closely related to the Kerguelen species Telmatogeton amphibius (Eaton) with which Sublette \& Wirth (1980) agreed and mentioned that it is also close to a species from the Antipodes Islands. Wings strongly reduced.

Smittia sp. ?

Recorded by Brundin (1962) who believed it to be restricted to Macquarie Island; possibly a parthenogenctic species that has bever been described. (Specimens labelled Pseudosmitria sp.).

Two further species of chironomid were collected in the summer of 1986-87 in two different genera and are currently being studied by P. Cranston.

\section{SCIARIDAE}

\section{Bradysia watsoni Colless 1962}

An endemic species according to Watson (1967) but there are many undescribed species of sciarids in collections from neighbouring regions (D. Colless, pers. comm.). This species is winged while Heard Island has wingless endemic in this family.

Evenhuis (1989) records another species from Macquarie Island, Sciara womersleyi Séguy 1940. This species was erected by Séguy for an unnamed sciarid described by Womersley (1937d) from two females from Kerguelen Island. Womersley also had a single sciarid from Macquaric lsland which he belicved was the same species. Because $S$. womersleyi was inadequately described, it must remain species inquirenda for the present. (D. Colless, pers. comm.)

\section{DOLICHOPODHDAE}

Schoenophilus pedestris pedestris Lamb $1909+$ Redescribed by Harrison (1959) and endemic according to Harrison (1976). Another subspecies oceurs on Auckland and Campbell Islands. Wings reduced.

\section{HELCOMYZIDAE}

Paractora asymmetrica (Enderlein 1930) ? = Actoceles asymmetrica Enderlein 1930

Not scen since the original collection which has not been restudied. There is doubt as to the family placing of this species (Harrison 1976).

\section{COELOPIDAE}

Coelopella plebeia Malloch 1933 \& = Coelopa

macquariensis Womersley 1937

This species is restricted to Macquaric Island according to Mathis (1989) who is not in agreement with Harrison's (1976) synonymy of this species with Coelopa Fucomyia curvipes Hutton 1902 from Auckland and Chatham Islands and New Zealand. McAlpine currently revising the Australian Coelopidae.

Icaridion debile Lamb 1909 I = Coelopa nigrifrons Lamb 1909

According to Harrison (1976), this species occurs on Campbell and Auckland Islands, the Antipodes, The Snares and mainland New Zealand as well as Macquarie Island. McQuillan \& Marker (1984) omitted to record the synonyny made by Harrison (1976).

\section{CARNIDAE}

Australimyza macquariensis (Womersley 1937) $\dagger=$

Procenace macquariensis Womersley 1937

Endemic according to Harrison (1976); it is common and belongs to an endemic genus for the New Zealand biogeographic region. Another species in the genus is found in Antipodes, Auckland and Campbell Islands and The Snares.

\section{EPHYDRIDAE}

Ephydrella macquariensis (Womerslcy 1937) $\dagger=$ Ephydra macquariensis Womersley 1937

An endemic species for Macquarie Island according to Harrison (1976); Bock (1987) recorded it erroneously from New Zealand subantarctic islands.

Amalopteryx maritima Eaton 1875 \#

This species is also known from Heard, Crozet and the Kerguelen Islands according to Womersley (1937d) but is a misidentification for Apetaenus watsoni according to 
Watson (1967). Only one specimen was recorted by Woncrsley (1937).

TETHINIDAE

Apetaenus watsoni Hardy $1962+$

A wingless species and apparenty restricted to Macquaric Island according to McQuillan \& Marker (1984). Womersley (1937d) recorded this specics as Apetaenus litoralis Eaton 1875 which is from the Kerguelen Islands, but this is a misidentification according borrison (1976). The recond is listed in Eventuis (1989) under Aperemes litoralis.

CHLOROPIDAE

Thyridula sp.?

Recorded by Sabrosky (1962) from Langaion Point and known from only two specimens which were not studied by Harrison (1976).

\section{LEPIDOPTERA: PYRALIDAE}

Eudonia mawsoni (Womersley \& Tindale 1937) $\dagger=$ Scoparia mawsoni Womersley \& Tindale 1937 nov. comb.

Redescribed by Common (1962) and considered endemic, although J. Dugdale (pers. comm.) has compared specimens with congenerics from New Zealand and its subantarctic islands and states that "the genitalia are not readily distinguished from specimens of Eudonia psammitis from South Island". The Macquarie Island specimens belong to the New Zealand wide E. psammitis (Meyrick) group of populations and this "species has a tendency to have local populations" (J. Dugdale, in litt.). The Macquarie Island population is therefore more accurately described as a geographical race rather than a distinct species. Generic name incorrectly used by Common (1962) and Watson (1967) as Eudoria (M. Shaffer, in litt.).

\section{HYMENOPTERA: DIAPRIIDAE}

Antarctopria latigaster Brues 1920 q

Recorded by Yoshimoto (1962) and redescribed by Early (1978, 1980). Also known from Stewart, Antipodes, Auckland and Campbell Islands, The Soares and the New Zealand mainland.
Sellonidue gen. si. sp. inder. ?

A single species recolded by Yoshimoto (1962) from Green Gorge but has not been recollected.

\section{ARACHNIDA \\ ARAENAE: DESTOAI: \\ Myo kergutenensis Cumbridge 1876 : $=$ Myo hamilomi logg 1909}

Rambow (1917) redestbel the specios M. hambon and exammed Hoge's lypes. He commented that $M$. homilton was closely related to $M$. kergutemsis Cambridge. These species were synonymised by Hickman (1939) after. examination of Ranbow's material. The species is known from Crozet, Heard, Marion and Kerguelen Lslands (Forster 1962.1970, Lawrence 1971), Lawrence considers it may have been introduced to Marion island.

L. YNPHILAE

Parafroneta mamineri (Hogg 1909) $\$=$ Mynoglenes marrineri Hogg 1909

Also known from Campbell, Auckland, Antipodes and Enderby Islands (Hickman 1939, Watson 1967, Forster \& Blest 1979).

Haplinus rafocephatia (Urquart 1888) \#

Mynoglenes rafocephalia (Urquart 1888) =

Mynoglenes insolens Simon 1905

Recorded by Hickman (1939) and also known from Chatham, Campbell and Auckland Islands but according to Watson (1967) may have been misidentified.

HAHNIIDAE

Hahnia sp. \#?

Forster (1955) recorded a Hahnia species from Auckland Island and quotes that "Hickman (1931)" recorded a species from Macquarie Island. No trace of this record can be found and I conclude that Forster was mistakenly referring to Hickman's (1939) descriptions of Hahnia crosentensis from Crozet Island.

Only two species of spiders, Parafroneta marrineri and Haplinus rufocephalia were collected in 1986/87. Both were common and abundant. 